\title{
Water recharge and discharge areas in towns and cities in Zambia
}

\section{Opinion}

I have been working in the water sector as a Social Worker for the past 22 years, initially as a Senior Community Development Officer in Institutional Building component under CARE International in Zambia for 8 years and Nkana Water and Sewerage Company as Senior Community Development Officer under Low Income Communities Support unit and Inspections for 14 years. A single worry I have had all these years has been that I have never seen Government take a stance on water recharge and discharge areas in Towns and Cities. There may be policies on these issues but personally I have not seen this issue adequately covered because this is evidently seen by the way plots are being allocated in towns and Cities without regard to whether the area is a recharge or discharge for a river. I reside in Copper-belts Kitwe Township a town which hosts mining activities and is a passage for one of Zambia's largest rivers called Kafue River. The Kafue River is one of the sources of water to a number of towns and Cities along the line of rail. Here in Kitwe there are visible areas which personally as a concerned resident has seen over a number of years served as recharge and discharge areas in a number of residential areas where recently have buried with gravel to pave way for domestic and commercial structures. The sad part is that even as members of water utilities we unable to react to this outstanding challenge. Sometimes I ask myself on how I can petition local authorities on the same without documentations and publicized laws that deal with environmental protection. Beside one wonders what set of rules govern this field. The people tasked with are not working in tandem with local authorities when comes to protecting these key points in our towns and Cities. This trend is common is all towns and Cities. When I contacted one of the Engineers in one of the cities around I was told that actually it has never cliqued in his mind to investigate on this important issue but was quick to state this is a common problem in all our towns and cities.

However, what is evident is that there are lots of materials and publications on the net that suggest that studies have been carried out in various areas to suggest to bring this issue home to relevant authorities in order for them to address the issue under discussion but if it has been done not enough policy direction has been given and key stakeholders fully involved.

In the book entitled "Zambezi River Basin - Atlas of the changing Environment" the author wrote and I quote

The Zambezi River Basin Atlas of the Changing Environment is a basin collaborative initiative with the objective of providing scientific evidence about changes that are taking place in the natural resources and the environment. The Atlas, with climate change as its running theme, is for use by policy makers and other stakeholders, and the general public, to generate action towards climate resilience through adaptation and mitigation of the impacts of climate change.

What I am saying is that this information is not readily available to Water Utilities and policy makers in the water industry I would love to see community focal persons, water Utilities representatives, local authorities, opinion leaders and civic leaders around the table discussing these issues because they do affect all of them. Keeping
Volume 3 Issue I - 2019

\author{
Mutale Nkonde \\ Department of hydrology, Africa Ground water network, \\ Zambia
}

Correspondence: Mutale Nkonde, Department of hydrology, Africa Ground water network, KITWE, Zambia,Tel +260955993601/0966436574, Email nkondem@nwsc.com.zm

Received: June 20, 2018 | Published: February 18, 2019

information on the corridors of powers and Universities won't help to develop our nations.

Information is power we all know therefore keeping to one or a few privileged class of people won't help in many cases to develop our global village. The role of research is to bring about development in many sectors of human endeavor therefore world renowned research bodies and academia should lead by example to highlight results of research with key stakeholders to ensure the developmental agenda is achieved. Local Governments and the technocrats should also ensure that research is not done for academic or commercial purposes but development. We have a responsibility to plan for the future $40-100$ years ahead so that posterity does not judge us harshly as the English saying goes. The leaders of today have virtually little sense of responsibility to its future generation. Let us leave the Earth better for the next generation to come by managing our economies and resources prudently. On $20^{\text {th }}$ June 2018 around 15:10 Zambian time I was winding down on this article I got an invitation to attend the $3^{\text {rd }}$ Africa Water Desalination Symposium and below is the letter written to potential delegates to this symposium concerning water and I quote

\section{Dear Delegate,}

Water scarcity or lack of safe drinking water is one of the world's leading problems affecting more than 1.1 billion people globally, meaning that one in every six people lacks access to safe drinking water. As more people migrate from rural areas into African cities, immense pressure is placed on already strained water resources in African cities. In South Africa's Cape Town for example, the crisis is so serious that authorities have predicted that if consumption levels remain unchecked, the city's water system could collapse on the 29th of April 2018. Latest figures show that dams are only 33 percent full and consumption has risen to 641 million litres per day.

\section{$3^{\text {rd }}$ africa water desalination symposium}

As you can see water the main stay of life has become scarce in most countries yet even where it is abundance not enough care is given to ensure that this economic good is protected from abuse. How can I as an individual add my voice against world voices that speak against these bad practices against this precious resource called water? This article briefly highlights some of the concerns I have over it. The other challenge is mining which is a big business in this Country called Zambia one of its big "by product" of Mining is water. During mining a lot of water is released from underground and discharged into rivers and eventually ends into dead seas and oceans, and as a country 
we do not harvest this precious commodity. How can the world out there help Zambia use this resource adequately in tourism, hydro generation, farming and many other business ventures? Has anyone in Zambia got the copper water foot print? I would be glad that this information is shared. There are a lot of things we do not know and which work against us. I was privileged to attend a water foot print workshop in Pretoria South Africa I think in the year 2014 or 15 and was shocked to learn that it takes 4000 liters of water to produce a $\mathrm{kg}$ of beef - surely what a waste of water in the so called modern ways of high beef production. People must be given the truth so they can take a position to change on some matters of grave importance.

We boast of having large water bodies yet we suffer from drought year in and year out due to global warming. Last rain season was not favourable for farming and personally I had to withdraw from farming to avoid incurring losses but if we had alternatives in terms of water supply such as dams and canals then I and other peasant farmers would have definitely taken advantage of other options. Water is life we are told and know it, but we have not done enough to preserve this economical good. Zambia which way forward with this issue I am left to wonder? It is only quite recent that the Ministry of Water, Sanitation, Energy and Environmental Protection was formed to safeguard the said resources, however not enough has been publicized and done to ensure that these resources are protected to required standards. One weak element about most Governments in Africa or even outside our continent is the failure to involve locals in research and development. Most of these researches done that seem scientific most times than often do not involve locals from the beginning to the end yet drivers of the same anticipant great results from their program- sorry it does not work that way.

Over the years, I have served in the water sector in my Country no one has ever involved me in policy formulation either as a citizen or as a beneficiary of the resource and not even as a partner in the sector yet programs want to see positive results. As an employee of a water - Commercial Utility Company I struggle to convince our customer on the importance of preserving this commodity not because we are mandated to as a Company but because I know that this product must jealously be guarded because it's not infinite for in other countries this good is not available 24/7 and that even us as Zambia one day we will woke up and find it has stopped flowing. I know that currently though we have challenges in providing this service to our target audience when our population is quiet small 14 million people - what more when we will have grown up. Currently due to poor network inherited by Commercial Water Utilities from municipalities that were initially tasked to provide this services to the citizenry of particularly boundaries, the unaccounted for water is as high as $60 \%$ in most cases. If you looked carefully at what I have discussed it goes to suggest that we are not well placed when it comes to water management generally.

The problem I fore see is the failure to manage this resource in the following manner

Firstly, we are disturbing the ecology by building on both recharge and discharge areas, though I am not an expert in hydrology yet I know that water is trapped in certain points for it to find its way in underground streams which in turn feeds rivers and lakes, the water we all want to access for various use. Water has many competing needs such as fishing, transport, hydro power production, farming and drinking just to mention a few.

Secondly urbanization is the main culprit for depreciating this healthy resource. We have seen how deforestation near river banks and in other areas has contributed to global warming and climate change. Timber harvesting and charcoal burning has claimed large chunks of land in very years what more with the increase of electricity prices and farming in put some local community still practices tree cutting and burning as a form of farming

Thirdly, mining has depreciated our underground water resource and this water goes out untapped leaving most lands arid and drought has taken toil in its place. Fourthly, we have a number of unplanned settlements that are now getting legalized that exists along the said river and the issues of pollution have arisen. I am afraid I can't even dare get into further details on this matter. The Governments of this Continent must work hand in hand with its technocrats to resolve this problem. Water management in Zambia, Zimbabwe, or Angola affects one or two countries in the regional and beyond in terms of water availability. Resources can be put together to build more dams for water rather let it to waste at the rate we are doing it .We are all guilty of mismanaging water which is life.

\section{Zambezi River basin - atlas of the changing environment}

August 14, 2017 by Routledge

Reference - 256 Pages - 134 Color Illustrations

ISBN 9781138240902 - CAT\# Y310671

Series: Earth scan Series on Major River Basins of the WorldThe article on this book was published on the internet and I believe it is not available in Zambia, the publisher advised that the books can be accessed on Hardback - $£ 84.00$ eBook $£ 35.99$ and eBook Rental for $£ 20.00$.

The book highlights the following features

a. Presents the most comprehensive synthesis of current knowledge on water resources management in the Zambezi, including biophysical, socioeconomic, policy, institutions and governance issues in a solutions-oriented manner.

b. With contributors working in the region, as well as others from Europe and North America, provides both an objective yet grounded assessment of current and future policy options for sustainable development.

c. Shows important lessons applicable globally concerning transboundary water management and the challenges of balancing conflicting demands for water resources for agriculture and hydropower.

\section{Acknowledgments}

None.

\section{Conflicts of interest}

The author declares that there is no conflicts of interest. 